\title{
Methicillin-resistant Staphylococcus aureus Septic Arthritis: A Case Report with the Possible Colchicine Effect to the Bacterial Persistence
}

\author{
Metisilin Dirençli Staphylococcus aureus Septik Artriti Olgu Sunumu: Kolşisinin Olası Etkisi
}

\author{
(1) Naciye Betül BAYSAL1, (1) Ahmet Naci EMECEN2, (1) Ferhat ARSLAN1, (1) Haluk VAHABOĞLU1 \\ 1istanbul Medeniyet University Faculty of Medicine, Department of Infectious Diseases and Clinical Microbiology, Istanbul, Turkey \\ 2Dokuz Eylül University Faculty of Medicine, Department of Public Health, Izmir, Turkey
}

Keywords: Septic arthritis, MRSA, teicoplanin, cotrimoxazole, relapse

Anahtar Kelimeler: Septik artrit, MRSA, teikoplanin, kotrimoksazol, relaps

Dear Editor,

Septic arthritis is an infection of the joint and presents with signs of inflammation. Microorganisms cause septic arthritis due to bacteremia or by spread from periarticular soft tissue or direct inoculation during surgery. Staphylococcus aureus is the most common cause of acute-onset and rapidly progressive bacterial arhritis ${ }^{[1]}$.

Bone and joint infection with S. aureus may lead to chronicity with relapses ${ }^{[1]}$. Rheumatologic diseases and some medications may affect the clinical course of infection. Herein, we aimed to present a case of relapsed methicillin-resistant S. aureus (MRSA) septic arthritis in a patient using colchicine and to review the factors associated with possible bacterial persistence.

A 30-year-old woman was admitted to our hospital with redness, swelling, and tenderness in the right knee for four days. In her medical history, it was learned that she was diagnosed with immune thrombocytopenic purpura secondary to systemic lupus erythematosus (SLE), which had been treated with methylprednisolone for four months. While using methylprednisolone, she had developed avascular necrosis in the right knee complicated with MRSA septic arthritis (Table 1). In this period, magnetic resonance imaging (MRI) revealed increased synovial fluid, osteonecrosis, and wide areas of fluid signal intensity posterosuperiorly. She had been treated with daptomycin for four weeks with repeated arthrocentesis. After completing antibiotherapy, she was discharged with hydroxychloroquine and colchicine for SLE. Two months later, symptoms recurred in the same knee and were successfully treated with empirical vancomycin, although synovial cultures yielded no microorganisms. She had been under treatment with hydroxychloroquine and colchicine until admission to our clinic for her third attack. Vital signs and systemic examinations were normal. Her right knee was warm, swollen, and tender. Joint movements were restricted. White blood count was 12900/mm $\mathrm{mm}^{3}$ (77\% neutrophil), C-reactive protein was $16.7 \mathrm{mg} / \mathrm{dl}(0-0.5 \mathrm{mg} / \mathrm{dl})$, and erythrocyte sedimentation rate was $94 \mathrm{~mm} /$ hour. Rose Bengal test was negative. Tuberculin skin test caused no induration. Magnetic resonance imaging was similar to the previous one, showing multilocular fluid collections in the soft tissue around the posterior and medial aspects of the articulation connected with joint space in the right knee (Figure 1). Imaging-guided drainage was performed 


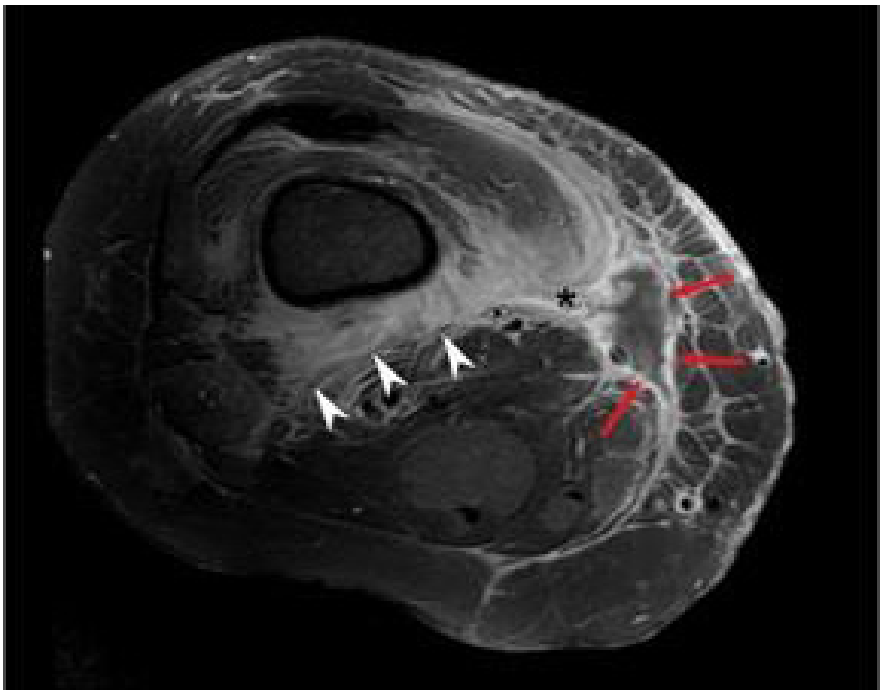

Figure 1. Magnetic resonance imaging of the patient's right knee showing abscess formation in the soft tissue (red arrows), inflammation extending to the joint (white arrows), and connection between the abscess and knee joint (black star)

by an invasive radiologist. Abscess material contained abundant leukocytes and MRSA was isolated in synovial culture (Table 1). Repeated arthrocentesis was performed by an orthopedic surgeon. Daptomycin $4 \mathrm{mg} / \mathrm{kg}$ was started. The patient responded well with antibiotherapy and was discharged on day 14 with teicoplanin 400 $\mathrm{mg} /$ day and trimethoprim/sulfamethoxazole $(320 \mathrm{mg} /$ day, based on trimethoprim). No relapse was observed after six months of followup.

In our case, MRSA possibly relapsed with the complications of septic arthritis and soft tissue abscess three years after the first attack. This led us to investigate the predisposing factors of bacterial persistence.

Bone infarcts and avascular necrosis of bone following highdose corticosteroid use in patients with SLE have been reported as risk factors for $S$. aureus bone and joint infections. Multifocal and relapsing infection is usually detected in these patients ${ }^{[2]}$.

S. aureus reduces its metabolism and growth by forming small colony variants for long-term survival in bone tissues. It is shown that stress-induced staphylococcal transcription factor sigma $B$ is a regulator of persistence in $S$. aureus in bone tissue ${ }^{[3]}$. Biofilm formation contributes to immune evasion and antibiotic resistance. Another study revealed that recurrent $S$. aureus isolates were less virulent but produced more mature biofilm and persisted longer in osteoblasts ${ }^{[1]}$.

S. aureus is capable of invading osteoblasts, which may play a role in recurrence and chronic osteomyelitis. Eradication of intracellular S. aureus with well-known antistaphylococcal antibiotics is challenging because most have poor intracellular

Table 1. Laboratory results, antibiotic susceptibility testing results, and antibiotic regimens used in each episode

\begin{tabular}{|c|c|c|c|c|}
\hline & & $1^{\text {st }}$ attack & $2^{\text {nd }}$ attack & Current attack \\
\hline \multirow[t]{2}{*}{ WBC count (cells $/ \mathrm{mm}^{3}$ ) } & Admission & 6700 (70.4\% PMNL) & 7200 (72\% PMNL) & 12900 (77\% PMNL) \\
\hline & Discharge & 6400 (63\% PMNL) & 6300 (63\% PMNL) & 6000 (69\% PMNL) \\
\hline \multirow[t]{2}{*}{ CRP (mg/dl) } & Admission & 30 & 12 & 16.7 \\
\hline & Discharge & 12.6 & 1.8 & $<0.10$ \\
\hline \multirow[t]{8}{*}{ S. aureus ASTs* } & FOX & $\mathrm{R}$ & + & $\mathrm{R}$ \\
\hline & VAN & $\begin{array}{l}\mathrm{S} \\
\text { (MIC: } \leq 0.5 \mu \mathrm{g} / \mathrm{ml})\end{array}$ & + & $\begin{array}{l}\mathrm{S} \\
(\mathrm{MIC}: \leq 0.5 \mu \mathrm{g} / \mathrm{ml})\end{array}$ \\
\hline & TEC & $\begin{array}{l}\text { S } \\
\text { (MIC: } \leq 1 \mu \mathrm{g} / \mathrm{ml} \text { ) }\end{array}$ & + & $\begin{array}{l}\text { S } \\
(\mathrm{MIC}: \leq 1 \mu \mathrm{g} / \mathrm{ml})\end{array}$ \\
\hline & DAP & $\begin{array}{l}\text { S } \\
\text { (MIC: } 0.25 \mu \mathrm{g} / \mathrm{ml} \text { ) }\end{array}$ & + & $\begin{array}{l}\text { S } \\
\text { (MIC: } 0.25 \mu \mathrm{g} / \mathrm{ml} \text { ) }\end{array}$ \\
\hline & CIP & $\begin{array}{l}\text { S } \\
\text { (MIC: } \leq 0.5 \mu \mathrm{g} / \mathrm{ml})\end{array}$ & + & $\begin{array}{l}\mathrm{S} \\
(\mathrm{MIC}: \leq 0.5 \mu \mathrm{g} / \mathrm{ml})\end{array}$ \\
\hline & $F A$ & $\begin{array}{l}\mathrm{S} \\
\text { (MIC: } \leq 0.5 \mu \mathrm{g} / \mathrm{ml})\end{array}$ & + & $\begin{array}{l}\mathrm{S} \\
(\mathrm{MIC}: \leq 0.5 \mu \mathrm{g} / \mathrm{ml})\end{array}$ \\
\hline & SXT & S & + & $\begin{array}{l}\mathrm{S} \\
(\mathrm{MIC}: \leq 10 \mu \mathrm{g} / \mathrm{ml})\end{array}$ \\
\hline & TE & $\begin{array}{l}\text { S } \\
\text { (MIC: } \leq 1 \mu \mathrm{g} / \mathrm{ml})\end{array}$ & + & $\begin{array}{l}\text { S } \\
\text { (MIC: } \leq 1 \mu \mathrm{g} / \mathrm{ml})\end{array}$ \\
\hline Treatment & & DAP $4 \mathrm{mg} / \mathrm{kg}$ (28 days) & VAN $2 \times 1$ gr (28 days) & $\begin{array}{l}\text { DAP } 4 \mathrm{mg} / \mathrm{kg} \text { ( } 14 \text { days); TEC } 400 \mathrm{mg} / \mathrm{day}+ \\
\text { SXT } 320 \mathrm{mg} / \text { day, based on trimethoprim ( } 28 \\
\text { days) }\end{array}$ \\
\hline
\end{tabular}

${ }^{*}$ Antimicrobial susceptibility results were interpreted according to Clinical and Laboratory Standards Institute criteria; ${ }^{+}$Culture was negative in the second episode. WBC: White blood cell, PMNL: Polymorphonuclear leukocytes, CRP: C-reactive protein, ASTs: Antibiotic susceptibility tests, R: Resistant, S: Susceptible, FOX: Cefoxitin, VAN: Vancomycin, TEC: Teicoplanin, DAP: Daptomycin, CIP: Ciprofloxacin, FA: Fusidic acid, SXT: Trimethoprim-sulfamethoxazole, TE: Tetracycline, MIC: Minimum inhibitory concentration 
penetration. Studies of the ability of antibiotics to eradicate intraosteoblastic S. aureus reservoirs showed that rifampin, fluoroquinolones, and clindamycin were highly efficient ${ }^{[4]}$. Daptomycin may be much less efficient intracellularly, probably because of the low $\mathrm{pH}$ surrounding intracellular $S$. aureus in lysosomes. However, hydroxychloroquine taken concurrently might alkalinize these vesicles, leading to increased daptomycin activity ${ }^{[5]}$.

S. aureus may survive in osteoblasts for a long time. In addition to serving as a reservoir for $S$. aureus, invaded osteoblasts were found to secrete high levels of interleukins ${ }^{[6]}$. The inflammatory process helps to eradicate bacteria but may induce soft tissue and bone destruction.

The internalization process is dependent on cytoskeletal elements. Blockers of these elements inhibit invasion. One of the drugs that inhibit microtubules is colchicine. Colchicine binds to free tubulins and impedes microtubule polymerization. It suppresses inflammation, particularly by preventing neutrophil chemotaxis and lysosomal enzymes ${ }^{[7]}$. Depolymerization of microtubules by colchicine reduces uptake of $S$. aureus by osteoblasts ${ }^{[8]}$. It has also been seen that some colchicine derivates have antibacterial effects on MRSA ${ }^{[0]}$.

In our patient, we isolated a strain of $S$. aureus with the same susceptibility pattern as the patient's previous isolate from three years earlier, but we were not able to show whether they were the same strains or not via molecular methods. The mild course and absence of systemic inflammatory response suggest that the septic arthritis might have resulted from local spread rather than septicemia. Osteomyelitis, the long-term outcome of chronic bacterial infection, was not observed on MRI. This can be explained by the anti-inflammatory and antibacterial effects of colchicine as well as the reduced internalisation of S. aureus.

Clearing the pus from the affected joint is mandatory in septic arthritis treatment and this is another topic that should be discussed in patients with relapses. Either imaging-guided drainage or repeated arthrocentesis were performed in the first and last attack. The patient had multilocular fluid collections in the soft tissue surrounding the posterior articulation area, which was thought to be the starting point of joint-associated infection. Surgical drainage would be preferred for soft tissue extension but there is not enough evidence showing the superiority of surgical drainage over arthrocentesis ${ }^{[10]}$.

In conclusion, the patient's immune status (SLE, corticosteroid use), underlying joint condition (bone infarcts and avascular necrosis), virulence factors of $S$. aureus, methicillin-resistance, ineffective drainage procedures, lack of combination therapy in initial episodes, and the $S$. aureus/osteoblast interaction might have contributed to the possible persistent infection. The interaction between S. aureus and osteoblasts is one of particular interest to prevent chronic bone and joint infections with S. aureus. Colchicine is generally used for its anti-inflammatory effects. However, it may change the course of chronic infections and modify the clinical presentation of staphylococcal infections by altering the interaction between $S$. aureus and osteoblasts.

\section{Ethics}

Informed Consent: Consent form was filled out by the presented case.

Peer-review: Externally and internally peer-reviewed.

\section{Authorship Contributions}

Concept: F.A., Design: F.A., A.N.E., Data Collection or Processing: F.A., A.N.E., Analysis or Interpretation: A.N.E., H.V., Literature Search: N.B.B., A.N.E., H.V., Writing: A.N.E., F.A., N.B.B.

Conflict of Interest: No conflict of interest was declared by the authors.

Financial Disclosure: The authors declared that this study received no financial support.

\section{References}

1. Trouillet-Assant $\mathrm{S}$, Lelièvre $\mathrm{L}$, Martins-Simões $\mathrm{P}$, Gonzaga $\mathrm{L}$, Tasse J, Valour $F$, Rasigade JP, Vandenesch F, Muniz Guedes RL, Ribeiro de Vasconcelos AT, Caillon J, Lustig S, Ferry T, Jacqueline C, Loss de Morais G, Laurent F. Adaptive processes of Staphylococcus aureus isolates during the progression from acute to chronic bone and joint infections in patients. Cell Microbiol. 2016;18:1405-14.

2. Galindo M, Mateo I, Pablos JL. Multiple avascular necrosis of bone and polyarticular septic arthritis in patients with systemic lupus erythematosus. Rheumatol Int. 2005;25:72-6.

3. Tuchscherr L, Geraci J, Löffler B. Staphylococcus aureus Regulator Sigma B is Important to Develop Chronic Infections in Hematogenous Murine Osteomyelitis Model. Pathogens. 2017:6.

4. Valour F, Trouillet-Assant S, Riffard N, Tasse J, Flammier S, Rasigade JP, Chidiac C, Vandenesch F, Ferry T, Laurent F. Antimicrobial activity against intraosteoblastic Staphylococcus aureus. Antimicrob Agents Chemother. 2015;59:2029-36.

5. Dupieux C, Trouillet-Assant S, Camus C, Abad L, Bes M, Benito Y, Chidiac C, Lustig $S$, Ferry $T$, Valour F, Laurent F. Intraosteoblastic activity of daptomycin in combination with oxacillin and ceftaroline against MSSA and MRSA. J Antimicrob Chemother. 2017;72:3353-6.

6. Bost KL, Ramp WK, Nicholson NC, Bento JL, Marriott I, Hudson MC. Staphylococcus aureus infection of mouse or human osteoblasts induces high levels of interleukin-6 and interleukin-12 production. J Infect Dis. 1999;180:1912-20.

7. Slobodnick $A$, Shah B, Pillinger MH, Krasnokutsky S. Colchicine: old and new. Am J Med. 2015;128:461-70.

8. Jevon M, Guo C, Ma B, Mordan N, Nair SP, Harris M, Henderson B, Bentley G, Meghji S. Mechanisms of internalization of Staphylococcus aureus by cultured human osteoblasts. Infect Immun. 1999;67:2677-81.

9. Huczyński A, Rutkowski J, Popiel K, Maj E, Wietrzyk J, Stefańska J, Majcher U, Bartl F. Synthesis, antiproliferative and antibacterial evaluation of C-ring modified colchicine analogues. Eur J Med Chem. 2015;90:296-301.

10. Ross JJ. Septic Arthritis of Native Joints. Infectious Disease Clinics North Am. 2017;31:203-18. 